\title{
Damir Horga
}

\section{BIBLIOGRAFIJA}

\section{do 1980.}

Horga, D. (1968). Diktanty po russkomu jazyku (uz AV tečaj ruskog jezika. A. Menac i Z. Volos). Zavod za fonetiku Filozofskog fakulteta, Zagreb. str. 50.

Horga, D. (1969). Scenarii po russkomu jazyku (uz AV tečaj ruskog jezika. A. Menac i Z. Volos). Zavod za fonetiku Filozofskog fakulteta, Zagreb. str. 30 i magnetofonska snimka.

Horga, D. (1971). Sistem fonetskih grešaka Francuza koji uče ruski. Govor, II, 3, 67 78.

Horga, D., Prosoli, A. (1972). Metode i tehnike praćenja glasa i govora. Simpozij "Dječji govor". Beograd.

Horga, D., Ilijaš, M., Pavuna, S. (1972). Russkij jazyk dlja detej (AVGS tečaj za djecu i priručnik za nastavnike). Školska knjiga. Zagreb, str. 144+130; dijafilmovi, magnetofonska vrpca.

Horga, D. (1973). Akustički aparati u osvajanju izgovora. Savjetovanje "Novo u nastavi stranih jezika". Institut za istraživanje i razvoj obrazovanja. Beograd.

Horga, D., Prosoli, A. (1973). Metode i tehnike praćenja glasa i govora. Zbornik Instituta za pedagoška istraživanja u Beogradu, br. 6, 153-166.

Horga, D., Ribarić, K. (1973). Glas poslije konzervacijskih i rekonstruktivnih zahvata u sonografskoj analizi. Čuvanje i uspostavljanje funkcije u kirurgiji gornjih dišnih puteva. Symposia otorhinolaryngologica Iugoslavica, Zagreb,179184.

Horga, D. (1974). Optimalna forma akustičkog kanala u učenju stranih jezika. Strani jezici, 2, 85-91.

Avakjan, R. V., Horga, D. (1974). Sbalansirovannye spiski slov dlja rečevoj audiometrii. Rasstrojstvo sluha i reči. Trudy Lenjingradskogo naučnoissledovatel'skogo instituta po boleznjam uha, gorla, nosa i reči. Tom XIX, 24-30. Moskva.

Horga, D. (1977). O učenju izgovora. Strani jezici, VI, 3-4, 191-195.

Avakjan, R. V., Horga, D. (1977). Spiski slov dlja rečevoj audiometrii, postrojennye na osnove vysotnyh harakteristik fonern. Voprosy fiziologii i patologii sluhovogo $i$ vestibuljarnogo analizatorov. Tom XXI A, 53-58. Moskva. 
Horga, D., Ribarić, K., Orešković, M. (1980). Auditivna ocjena nekih svojstava glasa. Symposia otorhinolaryngologica Iugoslavica, 15, 1, 25-38.

Horga, D., Ribarić, K., Orešković, M. (1980). Fonetska ocjena postoperativnog laringealnog glasa. XI kongres otorinolaringologa Jugoslavije. Aranđelovac.

Horga, D. (1980-81). Neki fonetski i vjerojatnosni faktori razumljivosti riječi. Suvremena lingvistika, 21-22, 19-37.

\section{od 1981. do 1990.}

Horga, D. (1981). Povezanost između stupnja poznavanja jezika i efikasnosti čitanja. Strani jezici, X, 1-2, 36-40.

Horga, D. (1981). Povezanost između stupnja poznavanja jezika i efikasnosti čitanja. II kongres Saveza društava za primijenjenu lingvistiku Jugoslavije. Zagreb. (knjiga sažetaka).

Horga, D., Mikulić, G. (1981). Metodološke osnove udžbenika jezika struke. Savjetovanje "Strani jezici struke u teoriji i praksi". Beograd. (knjiga sažetaka).

Štajner, S., Horga, D. (1981). Neoglotički glas. Savjetovanje otorinolaringologa. Dubrovnik.

Horga, D., Štajner, S., Sučić, M. (1981). Neoglotički glas i govor u ranom postoperativnom periodu. Symposia otorhinolaryngologica Iugoslavica, 16, 2-3, 341-256.

Horga, D., Mikulić, G. (1982). Metodološke osnove udžbenika jezika struke (na primjeru engleskog i ruskog). Strani jezici, XI, 1-2, 75-81.

Horga, D., Mikulić, G. (1983). Konceptualni paragraf kao jedinica znanstvenog diskursa. Strani jezici, XII, 4, 271-278.

Horga, D., Volos, R. (1983). Ruski jezik za studente društvenih $i$ humanističkih znanosti. SN Liber, Zagreb. str. 194.

Horga, D. (1983-84). Diskretnost govorne organizacije govornog teksta. Godišnjak Saveza društava za primijenjenu lingvistiku Jugoslavije. Sarajevo, 7-8, 137-144.

Benini, N., Horga, D., Nakić, A. (1983-84). Didaktički materijali za početno učenje gramatike. Godišnjak Saveza društave za primijenjenu lingvistiku Jugoslavije, 7-8, 269-276.

Horga, D. (1984). Faktori koji strukturiraju visinsku optimalu riječi. Simpozij "Govorne komunikacije". Zagreb.

Horga, D. (1984). Perceptivni spektar glasova. Simpozij "Govorne komunikacije". Zagreb. 
Horga, D. (1984). Razgovori o ruskom jeziku. Priručnik za učenike IV, V i VI razreda osnovne škole. Školska knjiga. Zagreb. str. 108.

Horga, D., Bilinić-Zubak, J. (1984). Gramatički priručnici za osnovnu školu. Savjetovanje o udžbenicima, priručnicima i drugom didaktičkom materijalu za nastavu stranih jezika. Školska knjiga, Zagreb i Zavod za udžbenike i nastavna sredstva, Beograd.

Horga, D., Mikulić, G. (1984). Jezična sredstva ostvarivanja povezanosti u pisanom filozofskom tekstu na primjeru engleskog i ruskog jezika. Istraživanja diskursa jezika struke 1. SN Liber. Zagreb, 20-36.

Horga, D. (1985). Simpozij "Govorne komunikacije". Strani jezici, XIV, 1-2, 92-96.

Horga, D. (1985). Upotreba govora. Školske novine, XXXVI, 3-4, 8-9.

Horga, D., Mikulić, G. (1985). Sažetak kao mjera razumljivosti. Savjetovanje "Razumijevanje teksta". Zagreb.

Horga, D., Papeš, Z. (1985). Auditivnost konsonanata u uvjetima komunikacije s bukom kao mogući element automatskog prepoznavanja govornih signala. Računalniška obdelava jezikounih podatkov. Bled, 605-608.

Mikulić, G., Horga, D., Biškupić, Lj. (1985). Udžbenik stranog jezika kao odraz jezičnog varijeteta. Savjetovanje "Jezični varijeteti i nastava jezika". Zadar.

Horga, D. (1986). Utjecaj fonetskih karakteristika na prepoznavanje filtriranih riječi. Govor, III, 2, 17-29.

Horga, D. (1986). Odnos konceptualne strukture izvornog i memoriranog teksta. IV. kongres Saveza društava za primijenjenu lingvistiku Jugoslavije. Herceg Novi.

Besermenji, M., Horga, D., Pavlačić, M. (1986). Zadaci za ispitivanje znanja iz ruskog jezika u IV i V razredu osnovne škole. Školska knjiga. Zagreb. str. $18+22$.

Horga, D., Pavlačić, M., Devčić, Lj. (1986). Skaži po russki, požalujsta. Udžbenik ruskog jezika i radni priručnik za učenike VII razreda osnovne škole. Školska knjiga. Zagreb. str. 132+64; audiokazete.

Horga, D. (1987). Odnos konceptualne strukture izvornog i zapamćenog teksta. Govor, IV, 1, 35-52.

Horga, D. (1987). Ruski vokali u fonetskom rešetu hrvatskosrpskih govornika. Deseta konferencija Međunarodne komisije za fonetiku i fonologiju slavenskih jezika. Akademija nauka i umjetnosti Bosne i Hercegovine. Sarajevo.

Horga, D. (1987). Savjetovanje "Fonološki i fonetski aspekti govorenog jezika u teoriji i primjeni". Govor, IV, 2, 181-184. 
Mikulić, G., Horga, D. (1987). Odlomak kao obavijesna jedinica teksta. X savjetovanje Saveza društava za strane jezike i književnosti Jugoslavije. Zagreb.

Mikulić, G., Horga, D., Biškupić, Lj. (1987). Udžbenik stranog jezika kao odraz jezičnog varijeteta. Zbornik radova znanstvenog skupa "Jezični varijeteti $i$ nastava jezika". Zagreb, 67-74.

Horga, D. (1988). Perceptivni spektar glasova. Defektologija, 24, 1, 17-40.

Horga, D. (1988). Odnos ritmičnosti i kognitivnih procesa u govorenom stručnom tekstu. Zbornik radova znanstvenog skupa "Deset godina obaveznog stranog jezika na Sveučlišstu: rezultati i problemi". Zagreb, 103-111.

Horga, D. (1988). Metodologija fonetskih istraživanja zadnjih deset godina Simpozijum "Lingvistička teorija i metodologija". Beograd.

Horga, D. (1988). Kultura govora i masovni mediji. Konferencija "Jezikot i kultura". Ohrid.

Horga, D., Jagatić, M. (1988). Zadaci za ispitivanje znanja iz ruskog jezika u VII razredu osnovne škole. Školska knjiga. Zagreb, str. 20.

Ježić, M., Horga, D. (1988). Modeliranje fonološkog sustava staroindoarijskoga sa sinkronijskim i dijakronijskim primislima. Savjetovanje "Fonetski i fonološki aspekti govornog jezika u teoriji i primjeni". Zagreb.

Mikulić, G., Horga, D. (1988). Optimal word forms of computer science terminology: purist or English. XIIth International Congress of Anthropological Sciences. Zagreb.

Horga, D., Pavlačić, M., Devčić, Lj. (1988). Višeizvorni sklop uz udžbenik ruskog jezika za VII razred osnovne škole. Skaži po russki, požalujsta (Didaktički materijali: kartice, dijapozitivi, igre, grafofolije). Školska knjiga. Zagreb.

Horga, D. (1989). Latentna struktura brzine izgovora. Govor, V, 2, 129-146.

Horga, D. (1989). Ruski vokali u fonetskom rešetu hrvatskosrpskih govornika. Zbornik referata Desete konferencije Međunarodne komisije za fonetiku ifonologiju slavenskih jezika. Akademija nauka i umjetnosti Bosne i Hercegovine. Sarajevo, 145-158.

Horga, D. (1989). Kultura govora i masovni mediji. Zbornik na trudovi "Jezikot $i$ kulturata". Skopje, 25-31.

Horga, D. (1989). Fonološki i fonetski aspekti govorenog jezika. Zbornik radova Društva za primïenjenu lingvistiku SRH. Zagreb, str. 239.

Horga, D. (1989). Struktura sposobnosti proizvodnje govora. V kongres Zveze društev za uporabno jezikoslovje Jugoslavije. Ljubljana. 
Ježić, M., Horga, D. (1989). Artikulacijski i akustički opis fonološkog sustava staroindijskoga. Govor, VI, 1, 1-42.

Ježić, M., Horga, D. (1989). Modeliranje fonološkoga sustava staroindoarijskoga. Zbornik znanstvenog skupa "Fonološki i fonetski aspekti govorenog jezika". Zagreb, 117-126.

Štajner, S., Horga, D., Sučić, M. (1989). Neoglotički glas i govor. Savjetovanje "Aktualno o larinksu". Klinika za otorinolaringologiju i cervikofacijalnu kirurgiju Medicinskog i stomatološkog fakulteta. Zagreb.

Horga, D., Ribarić, K., Miličič, D., Petric, V. (1989). Sonografska analiza glasa i govora nakon "near total" laringektomije. Savjetovanje "Aktualno o larinksu". Klinika za otorinolaringologiju i cervikofacijalnu kirurgiju Medicinskog i stomatološkog fakulteta. Zagreb.

Horga, D. (1990). Trajanje kao element interferencije mjereno pomoću kompjutora. Urednici Andrijašević, M., Y. Vrhovac: Informatička tehnologija u primijenjenoj lingvistici. Društvo za primijenjenu lingvistiku Hrvatske. Zagreb, 1-7.

Horga, D. (1990). Lspol'zovanije komp'juternoj tehnologii v lingvistike i fonetike. MGU im. M.V. Lomonosova. Moskva, 12.-14.6.1990.

Horga, D. (1990). Trajanje kao element interferencije mjereno pomoću kompjutora. Savjetovanje Društva za primijenjenu lingvistiku SR Hrvatske "Informatička tehnologija u primijenjenoj lingvistici". Zagreb, 16. i 17. ožujka 1990. (zbornik sažetaka).

Horga, D. (1990). Trinaesta godišnja skupština Društva za primijenjenu lingvistiku SR Hrvatske (18.10.1989.). Strani jezici, 19, 1-2, 85-86.

Mikulić, G., Horga, D. (1990). A Sociolinguistic Analysis of Attitudes Towards the Use of Native Versus Foreign Words. Editors: Filipović, R., M. Bratanić: Languages in Contact, 157-165.

\section{od 1991. do 2000.}

Horga, D. (1991). Neurolingvistička organizacija bilingvalnih govornika. Strani jezici, 20, 3, 147-159.

Horga, D. (1991). Utjecaj kulturoloških osobina slušaoca na oblikovanje ekonomskopropagandne poruke. Urednici Andrijašević, M., Y. Vrhovac: Prožimanje kultura $i$ jezika. Društvo za primijenjenu lingvistiku Hrvatske. Zagreb, 191-199.

Horga, D. (1991). Utjecaj kulturoloških osobina slušaoca na oblikovanje ekonomskopropagandne poruke. Savjetovanje Društva za primijenjenu 
lingvistiku Hrvatske "Prožimanje kultura i jezika". Zagreb, 12. i 13. travnja 1991. (zbornik sažetaka).

Horga, D., Sučić, M., Štajner-Katušić, S. (1991). Kvaliteta glasa i govora nakon totalne laringektomije. Symposia Otorhinolaryngologica, 26, 99-106.

Horga, D., Mušura-Kekić, M. (1991-92). Motorička kontrola proizvodnje govora. Govor, 8-9, 1-2, 91-111.

Bakran, J., Horga, D., Stamenković, M. (1991-92). Percepcija mjesta artikulacije bezvučnih okluziva. Govor, 8-9, 1-2, 31-47.

Horga, D. (1992). Varijabilitet govornih odsječaka. Suvremena lingvistika, 8, 2, 34, 81-92.

Horga, D. (1992). Akustička optimalizacija govornog signala u učenju izgovora. SUVAG, 5, 1-2, 71-75.

Horga, D. (1992). Lateralizacija jezika kojima govornik vlada. Urednici Andrijašević, M., Y. Vrhovac: Strani jezik u dodiru s materinskim jezikom. Društvo za primijenjenu lingvistiku Hrvatske. Zagreb, 167-177.

Horga, D. (1992). Lateralizacija jezika kojima govornik vlada. Savjetovanje Hrvatskog društva za primijenjenu lingvistiku "Strani jezik u dodiru s materinskim jezikom". Zagreb, 8. i 9. svibnja 1992. (zbornik sažetaka).

Horga, D. (1992). Ivo Škarić: "Fonetika hrvatskoga književnog jezika". Govor, 8-9, 1-2, 151-154.

Horga, D. (1992). "Fonetika hrvatskoga književnog jezika" Ive Škarića. Jezik, 40, 5, 153-156.

Horga, D. (1992). Hrvatsko društvo za primijenjenu lingvistiku. Strani jezici, 21, 2, 152-154.

Horga, D., Mikulić, G. (1992). Inferencije i čitanje na prvom i drugom jeziku. Strani jezici, 21, 2, 92-102.

Mikulić, G., Horga, D. (1992). Čitanje kao kognitivna aktivnost. Suvremena lingvistika, 18, 33, 45-54.

Horga, D., Sučić, M., Štajner, S. (1992). Kvaliteta glasa i govora nakon totalne laringektomije kao faktor komunikacije. IV. znanstveni skup Istraživanja na području defektologije, Zagreb, 1.-3. listopada 1992.

Mušura-Kekić, M., Horga, D., Sučić, M. (1992). Kontrola realizacije govornih motoričkih programa. Symposia Otorhinolaryngologica, 27, 133-140.

Horga, D. (1993). Značenje glasnika. Suvremena lingvistika, 35-36, 77-92. 
Horga, D. (1993). Fonetika i učenje stranih jezika. Urednici Andrijašević, M., Y. Vrhovac: Trenutak sadašnjosti u učenju jezika. Društvo za primijenjenu lingvistiku Hrvatske. Zagreb, 53-60.

Horga, D. (1993). Fonetika i učenje stranih jezika. Savjetovanje Hrvatskog društva za primijenjenu lingvistiku. Zagreb, 16. i 17. travnja 1993. (knjiga sažetaka).

Horga, D. (1993). David Singelton: Language Acquisition: The Age Factor. Multilingual Matters ltd, Clevedon-Philadelphia,1989. Strani jezici, 22, 3-4, 290-293.

Horga, D. (1993). O radu Odjela za fonetiku Hrvatskog filološkog društva od lipnja 1993. do lipnja 1994. godine. Govor, X, 1, 103-105.

Horga, D. (1993). Trenutak sadašnjosti u učenju jezika. Savjetovanje Hrvatskog društva za primijenjenu lingvistiku, Zagreb, 16. i 17. travnja 1993. Strani jezici, 22, 2, 162-164.

Sučić, M., Horga, D., Štajner, S. (1993). Kvaliteta glasa i govora alaringealnih govornika. IV. strokovno srečanje logopedov Slovenije "Multidisciplinarni pristop v logopediji". Društvo logopedov Slovenije. Portorož, 13.-15. svibnja 1993.

Horga, D. (1994). Horvatsko-russkaja interferencija (na materiale glasnyh). Vestnik Sankt Peterburgskogo universiteta, 2, 1(2), 70-77.

Horga, D. (1994). Tečnost govora u elektroničkim medijima. Govor, XI, 2, 15-22.

Horga, D. (1994). Varijabilitet glasa induciran jezikom. Urednici Andrijašević, M., Y. Vrhovac: Strani jezik u dodiru s materinskim jezikom. Društvo za primijenjenu lingvistiku Hrvatske. Zagreb, 1992, 167-177.

Horga, D. (1994). O slogu u hrvatskom jeziku. XI Miedzynarodowa Konferencja Miedzynarodowej Komisiji Fonetyki i Fonologii afiliowanej przy Miedzynarodowym Komitecie Slawistow. Torun (Poljska), 15.-17. studenoga 1994.

Horga, D. (1994). Varijabilitet glasa induciran jezikom. Savjetovanje Hrvatskog društva za primijenjenu lingvistiku. Zagreb, 18. i 19. travnja 1994. (knjiga sažetaka).

Horga, D. (1994). Rad Odjela za fonetiku Hrvatskog filološkog društva od lipnja 1993. do lipnja 1994. godine. Suvremena lingvistika, 38, 99-101.

Horga, D., Štajner-Katušić, S., Sučić, M. (1994). Osobina glasa i govora mjerene pomoću dugotrajnog srednjeg spektra. I. kongres logopeda Hrvatske. Hrvatsko logopedsko društvo. Varaždin, 21.-24.9.1994. 
Horga, D. (1995). The influence of the placement of word-boundary on the acoustic invariance of the syllable. Urednici K. Elenius, P. Branderud: Proceedings of The XIIIth International Congress of Phonetic Sciencies. Stockholm, Vol. 4, 424427.

Horga, D. (1995). Osobitosti govora simultanog prijevoda. Urednice MihaljevićDjigunović, J., N. Pintarić: Prevođenje: suvremena strujanja i tendencije. Zbornik radova savjetovanja HDPL. Zagreb, 31.3. i 1.4.1995., 385-394.

Horga, D. (1995). The influence of the placement of word-boundary on the acoustic invariance of the syllable. The XIIIth International Congress of Phonetic Sciencies. Stockholm, 12.-19.8.1995. (book of abstracts).

Horga, D. (1995). Osobitosti govora simultanog prijevoda. Savjetovanje Hrvatskog društva za primijenjenu lingvistiku. Zagreb, 31.3.-1.4.1995. (zbornik sažetaka).

Horga, D. (1995). Izvještaj o radu Odjela za fonetiku. Govor, XII, 2, 157-158.

Horga, D., Mildner, V. (1995). Optimala glasa mjerena vremenom brzine reakcije. SUVAG, 8, 1, 13-22.

Horga, D., Mildner, V. (1995). Differences in Formant-Defined English Vowel Space between Native Speakers and Croatian Students of English. Znanstveni skup Hrvatskog društva za anglističke studije "Anglistika u Hrvatskoj". Zagreb.

Modrić, V., Horga, D. (1995). Utjecaj slušne kontrole na trajanje izgovora glasnika. Govor, 12, 2, 111-124.

Landau, E., Lončarić, M., Horga, D., Škarić, I. (1995). Croatian. Journal of the International Phonetic Association, 25, 2, 83-86.

Horga, D. (1996). Obrada fonetskih obavijesti. Hrvatsko filološko društvo. Zagreb, str. 300.

Horga, D. (1996). Utjecaj fiksiranog zagriza na trajanje izgovora glasnika. Suvremena lingvistika, 22, 1-2 (41/42), 213-219.

Horga, D. (1996). Utjecaj položaja leksičke granice na slogovnu strukturu u hrvatskom govoru. Studia Slavica I, Acta Universitatis Nicolai Copernici. Torunj, 55-77.

Horga, D. (1996). Humor u javnim elektroničkim medijima. Urednici Andrijašević, M., L. Zergollern-Miletić: Jezik $i$ komunikacija. Hrvatsko društvo za primijenjenu lingvistiku. Zagreb, 70-77.

Horga, D. (1996). Govorni stilovi. XII medzinarodna konferencia Medzinarodnej komisie pre fonetiku a fonologiu slovanskych jazykov pri Medznarodnom komitete slovistov. Prešov, 17.-19.9.1996. 
Horga, D. (1996). Humor u javnim elektroničkim medijima. Savjetovanje HDPL "Jezik i komunikacija". Zagreb, 15. i 16. svibanj 1996. (knjiga sažetaka).

Bakran, J., Horga, D. (1996). SAMPA za hrvatski. Govor, 13, 1-2, 99-104.

Horga, D., Štajner-Katušić, S., Sučić, M. (1996.). Vremenska organizacija segmentalne razine govora alaringealnih osoba: trajajnje dvousnenih suglasnika. Symposia otorhinolaryngologica, 31, 1-2, 21-31.

Štajner-Katušić, S., Horga, D., Sučić, M. (1996). Analysis of the voice and speech with a long term average spectrum. Otorhino-laryngologia nova, 6, 1; 43-43

Štajner-Katušić, S., Horga, D., Sučić, M. (1996). The speech timing strategies in alaryngeal subjects. Urednici O. Ribari, A. Hirschberg: $3^{\text {rd }}$ European Congress of the European Federation of Oto-Rhino-Laryngological Societies. Budapest (Hungary) June 9-14, 1996, 445-448.

Štajner-Katušić, S., Sučić, M., Horga, D. (1996). Alaringealni glas i govor. Znanstveni skup "Rana dijagnostika i rana rehabilitacija". Buzina, T., Titl, I. (ur.). Zagreb: SUVAG.

Štajner-Katušić, S., Horga, D., Mušura, M., Sučić, M. (1996). The speach timing pattern in alaryngeal speakers. Drugi kongres otolaringologov Slovenije. Bled, Slovenija: Medicinski razgledi, Ljubljana, 37.

Horga, D. (1997). Samoispravljanje u govornoj proizvodnji. Suvremena lingvistika, 43-44, 1-2, 91-104.

Horga, D. (1997). Tečnost govora na radiju i televiziji. Urednik S. Damjanović: Zbornik radova Prvog hrvatskog slavističkog kongresa. HFD. Pula, 19.-23.9.1995.

Horga, D. (1997). Fonetske razlike govornog i čitanog diskursa. Urednici Andrijašević, M., L. Zergollern-Miletić: Tekst $i$ diskurs. Zbornik radova savjetovanja HDPL. Zagreb, svibanj 1997. 189-195.

Horga, D. (1997). XIII. znanstvena konferencija Međunarodne komisije za fonetiku i fonologiju slavenskih jezika Međunarodnog slavističkog komiteta. HFD. Zbornik sažetaka, str. 22.

Horga, D. (1997). Reorganizacija izgovora prilikom fiksiranog zagriza. Fonetika $i$ fonologija slavenskih jezika. Horga, D. (ur.): Hrvatsko filološko društvo, str. 21.

Horga, D. (1997). Fonetske razlike govornog i čitanog diskursa. Savjetovanje HDPL "Tekst i diskurs". Zagreb, svibanj 1997. (zbornik sažetaka).

Horga, D. (1997). Izvještaj o radu Odjela za fonetiku. Govor, XIV, 1-2, 149-151.

Horga, D., Mildner, V. (1997). Differences in formant-defined vowel space between native speakers of English and Croatian students of English. Studia Romanica et Anglica Zagrabiensia, 42, 155-166. 
Horga, D., Stanojević-Kryžan, B. (1997). Roznice w mowie pokolen na przykladze materialow z nagran radiowych i telewizyjnych. Konferencje Miasto - teren koegzystenciji pokolen. Lodz (Poljska), 19.-21.5.1997.

Horga, D., Štajner-Katušić, S., Sučić, M. (1997). Vremenska organizacija segmentalne razine govora alaringealnih govornika. Znanstveni skup "Rehabilitacija i inkluzija". Zagreb, 23.-26.9.1997. (zbornik sažetaka).

Horga, D., Štajner-Katušić, S., Sučić, M. (1997). Vremenska organizacija segmentalne razine govora alaringealnih govornika. Brestovci, B. (ur.): Rehabilitacija i inkluzija, Zagreb: Fakultet za defektologiju, 85-86.

Horga, D. (1998). Reorganizacija izgovora pri fiksiranom zagrizu. Govor, XV, 1, 3559.

Horga, D. (1998). Neutralizacija nekih akustičkih parametara u razgovornom hrvatskom. Croatica, 27, 45-46, 71-81.

Horga, D. (1998). The Long-Term Average Spectrum as a Measure of Voice Quality in L1 and L2 Speakers. IPS - 98: An International conference sponsored by the ISPhS. Bellingham (USA), 27.-30.6.1998. (book of abstracts).

Horga, D. (1998). Neutralizacija nekih akustičkih parametara u razgovornom hrvatskom. XII. Međunarodni slavistički kongres. Krakow (Poljska), 24.8.1.9.1998.

Horga, D. (1998). Palatalizacija u ruskom gledana kroz hrvatski. Konferencija Z zagadnien prozodii jezykow slovianskich. Torunj, 4.-5.5.1998.

Horga, D. (1998). Izgovorne pogreške. Sažeci. 3. znanstveni skup "Istraživanja govora". Škarić, I. (ur.). Zagreb: Hrvatsko filološko društvo, str. 21.

Horga, D. (1998). Prikaz Međunarodne konferencije IPS-98. Govor, XV, 1, 65-66.

Horga, D. (1998). Prikaz međunarodne konferencije Istraživanje prozodije slavenskih jezika. Govor, XV, 2, 153-154.

Štajner-Katušić, S., Horga, D., Sučić, M. (1998). Duration of bilabial consonats in esophageal and normal speakers. Acta clinica Croatica, 37, 4, 259-264.

Štajner-Katušić, S., Krapinec, S., Horga, D. (1998). Kakvoća glasa operiranih glasiljki (polipi). Sažeci. 3. znanstveni skup "Istraživanja govora". Škarić, I. (ur.). Zagreb: Hrvatsko filološko društvo, str. 49.

Horga, D. (1999). The Long-Term Average Spectrum as a Measure of Voice Quality in L1 and L2 Speakers. Zeitschfirt für Dialektologie und Linguistik, 106, 91-97.

Horga, D. (1999). Govorne pogreške. Savjetovanje HDPL Teorija i mogućnosti primjene pragmalingvistike. Opatija, 7.-8.5.1999. 
Horga, D. (1999). Development of the speech temporal patterns. Early communication and language development. Faculty of Special Education and Rehabilitation, University of Zagreb. Dubrovnik, 1.-4.10.1999.

Horga, D. (1999). Glasnički zglobovi i fonemski sadržaj. Vyraz a vyznam v jazyku. Prešov (Slovačka), 17.-18.9.1999.

Horga, D. (1999). Ruski palatalizirani suglasnici u dodiru s hrvatskim. Drugi slavistički kongres, Knjiga sažetaka. Sesar, D., Vidović, I. (ur.). Zagreb: Targa d.o.o., 101-102.

Horga, D. (1999). Development of Speech Temporal Patterns. Early Communication and Language Development 99 Abstracts. Zagreb: Birotisak, str. 78.

Horga, D. (1999). Izvještaj o radu Odjela za fonetiku. Govor, XVI, 1, 91-94.

Horga, D. (1999). Prikaz 6. konferencije o govornoj komunikaciji i tehnologiji Eurospeech 99. Govor, XVI, 195-197.

Erdeljac, V., Horga, D. (1999). Influence of morphology on phoneme identification in spoken Croatian. Eurospeech 99. Olaszy, G., Nemeth, G., Erdohegyi, K. (ur.). ESCA, 1891-1894.

Horga, D., Mildner, V. (1999). Temporal Characteristics of English Spoken by Native Speakers of Croatian. Proceedings of the 14th International Congress of Phonetic Sciences. Ohala, J.J., Hasegawa, Y., Ohala, M., Granville, D., Bailey, A. (ur.). San Francisco: International Phonetic Association, 1:755-758.

Mildner, V., Horga, D. (1999). Relations between second language proficiency and formant-defined vowel space. Proceedings of the 14th International Congress of Phonetic Sciences. Ohala, J.J., Hasegawa, Y., Ohala, M., Granville, D., Bailey, A. (ur.). San Francisco: International Phonetic Association, 2:1455-1458.

Lončarić, M., Landau, E., Horga, D., Škarić, I. (2000). Croatian. Handbook of the International Phonetic Association. Cambridge University Press, London, 66-69.

Horga, D. (2000). Izvještaj o radu Odjela za fonetiku. Govor, XVII, 2, 165-167.

Horga, D. (2000). Prikaz konferencije Promjene u fonetici slavenskih jezika od 1944. do 2000. godine. Govor, XVII, 1, 65-66.

Horga, D. (2000). Phonetics at the University of Zagreb, Croatia. The Phonetician, 82/2000-II, 29-32.

Horga, D. (2000). Engleski aspirirani zatvornici u dodiru s hrvatskim. Strani jezici, $3,129-141$. 
Horga, D., Hunski, M. (2000). The Influence Of The Orthodontic Treatment On The Articulation. ICPLA 2000. Hewlett, N, Windsor, F. (ur.). 8th Meeting of the International clinical phonetics and linguistics association, Edinburgh.

Horga, D., Mildner, V. (2000). Moždana lateralizacija u jezičnom prevođenju. Savjetovanje HDPL "Primijenjena lingvistika u Hrvatskoj - izazovi na početku XXI. stoljeća". Opatija, 19.-20.5.2000.

Horga, D., Mukić, I. (2000). Neki vremenski parametri govora u dnevnicima HTVa. Govor, XVII, 2, 105-127.

Štajner-Katušić, S., Horga, D. (2000). Akustičke karakteristike i perceptivna procjena polipoidnog glasa prije i nakon operacije. 1. znanstveni skup "Glas/Voice". Opatija, 26.-28.2. 2000.

Horga, D., Akrap-Kotevski, V., Ivičević-Desnica, J. (2000). Fonematska funkcija glasa u afazika. 1. znanstveni skup "Glas/Voice". Opatija, 26.-28.2.2000.

Hunski, M., Horga, D., Vrban Zrinski, K. (2000). Utječe li ortodontski aparat na glas? 1. znanstveni skup "Glas/Voice". Opatija, 26.-28.2.2000.

Štajner-Katušić, S., Horga, D., Krapinec, S. (2000). The Voice Before and After Vocal-Cord Polyp Removal. ICPLA 2000. Hewlett, N, Windsor, F. (ur.). 8th Meeting of the International clinical phonetics and linguistics association, Edinburgh.

\section{od 2001. do 2010.}

Štajner-Katušić, S., Horga, D. (2001). Akustičke karakteristike i perceptivna procjena polipoidnog glasa prije i nakon operacije. Znanstveni skup s međunarodnim sudjelovanjem "Glas/Voice". Varošanec-Škarić, G., Brestovci, B. (ur.). Zagreb: Hrvatsko filološko društvo, str. 32.

Horga, D., Akrap-Kotevski, V., Ivičević-Desnica, J. (2001). Fonematska funkcija glasa u afazika. Znanstveni skup s međunarodnim sudjelovanjem "Glas/Voice". Varošanec-Škarić, G., Brestovci, B. (ur.). Zagreb: Hrvatsko filološko društvo, str. 25.

Hunski, M., Horga, D., Vrban Zrinski, K. (2001). Utjecaj ortodontskog aparata na glas. Znanstveni skup s međunarodnim sudjelovanjem "Glas/Voice". VarošanecŠkarić, G. (ur.). Zagreb: Hrvatsko filološko društvo, 166-171.

Ivičević-Desnica, J., Hunski, M., Horga, D., Škarić, I. (2001). Prepoznavanje artikulacijskog statusa govornika s ortodontskim poremećajima na temelju vizualnog stimulusa. Cetvrti znanstveni skup s međunarodnim sudjelovanjem "Istraživanja govora". Ivas, I., Pletikos, E. (ur.). Zagreb: Odsjek za fonetiku Filozofskog fakulteta Sveučilišta u Zagrebu, 45-46. 
Horga, D. (2002). Tečnost kao izraz govornog stila. Fonicke javy v slovanskych jazykoch. Sabol, J. (ur.). Prešov: Nauka, 79-88.

Horga, D. (2002). The influence of bite - blocks on continuous speech production. Phonetics and its applications. Braun, A., Masthoff, H.R. (ur.). Eurasburg: Druckerei Proff, str. 143-152.

Horga, D. (2002). Moždana lateralizacija u jezičnom prevođenju. Primijenjena lingvistika u Hrvatskoj - izazovi na početku XXI. stoljeća. Stolac, D., Ivanetić, N., Pritchard, B. (ur.). Zagreb-Rijeka: Graftrade, d.o.o., 193-201.

Horga, D., Liker, M. (2002). Akcenatski status proklitika u govoru elektroničkih medija. Treći hrvatski slavistički kongres, Knjiga sažetaka. Zagreb-Zadar, 38-39.

Liker, M., Horga, D. (2002). Akustički opis naglasaka u hrvatskom u četiri urbana idioma. Treći hrvatski slavistički kongres, Knjiga sažetaka. Zagreb-Zadar, 45-46.

Horga, D., Mildner, V., Šindija, B. (2002). Temporal parameters of speech in the hearing-impaired children. 9th Meeting of the International clinical phonetics and linguistics association, Hong Kong.

Šindija, B., Mildner, V., Horga, D. (2002). The evaluation of speech of children with cochlear implants and hearing-aid users by trained and untrained listeners. 9th Meeting of the International clinical phonetics and linguistics association, Hong Kong.

Štajner-Katušić, S., Horga, D., Krapinec, S. (2002). The Voice of Polypoid Vocal Folds before and after Surgery. Investigations in Clinical Phonetics and Linguistic. Windsor, F., Kelly, M.L., Hewlet, N. (ur.). Mahwah, NJ, USA; London, UK : Lawrence Erlbaum Associate Publishers, 437-448.

Horga, D. (2003). Razvoj segmentalnih vremenskih obrazaca u govoru djece. Govor, $20,1-2,121-132$.

Erdeljac, V., Horga, D. (2003). Mentalno procesiranje morfoloških jedinica u govorenoj riječi. Psiholingvistika $i$ kognitivna znanost u hrvatskoj primijenjenoj lingvistici, Stolac, D., Ivanetić, N., Pritchard, B. (ur.). Zagreb-Rijeka: Hrvatsko društvo za primijenjenu lingvistiku, 239-247.

Horga, D., Hunski, M., Ivičević-Desnica, J. (2003). Temporal reorganization of articulation to an artificial palate. 15th international congress of phonetic sciences. M.J. Sole, D. Recesens, J. R. (ur.). Barcelona, 3161-3164.

Hunski, M., Ivičević-Desnica, J., Horga, D. (2003). Izgovorni i ortodontski poremećaji u predškolskoj dobi. Logopedija za vsa življenjska obdobja. Čepeljnik, J., Globačnik, B., Grobler, M., Jurček Strmišnik, B., Steiner, M. (ur.). Ljubljana: Tiskarna ACO, 37-40. 
Ivičević-Desnica, J., Hunski, M., Horga, D. (2003). Ortodontski i izgovorni poremećaji u predškolskoj dobi. Govor, 20, 1-2; 147-156.

Mildner, V., Šindija, B., Horga, D. (2003). Evaluation of Croatian-speaking children's speech with cochlear implants and comparison with hearing-aid users. Journal of Multilingual Communication Disorders, 1, 1; 63-70.

Štajner-Katušić, S., Horga, D., Vrban Zrinski, K. (2003). Akustičke karakteristike i perceptivna promjena polipoidnog glasa prije i nakon operacije. Logopedija za vsa življenjska obdobja. Čepeljnik, J., Globačnik, B., Grobler, M., Jurček Strmšnik, B., Steiner, M. (ur.). Ljubljana: Tiskarna ACO, 148-151.

Hunski, M., Ivičević-Desnica, J., Škarić, I., Horga, D. (2003). Odnos između ortodontskih i izgovornih poremećaja u adolescenata. Acta Stomatol Croat. Zagreb, 332-333.

Mušura, M., Štajner-Katušić, S., Globlek, D., Horga, D., Liker, M. (2003). Analiza alaringealnog glasa i govora. Treći kongres Hrvatskog društva za otorinolaringologiju i cervikofacijalnu kirurgiju, Plitvice, Hrvatska 21.-24. svibnja 2003. Došen, D. (ur.). Zagreb: Hrvatsko društvo za otorinolaringologiju i cervikofacijalnu kirurgiju, str. 147.

Runjić, N., Mildner, V., Horga, D., Šindija, B., Gregl, A. (2003). Hemisphere dominance in cochlear implanted children. Neurologia Croatica. 52, Suppl. 4; 63.

Mušura, M., Štajner-Katušić, S., Globlek, D., Horga, D., Vrban Zrinski, K., Večerina Volić, S. (2003). Alaringealni glas i govor. Prvi kongres otorinolaringologa i cervikofacijalnih hirurga/kirurga Bosne i Hercegovine. Sarajevo.

Horga, D., Liker, M. (2004). Voice and pronunciation of cochlear implant speakers. 10th Meeting of the International clinical phonetics and linguistics association, Lafayette.

Horga, D., Liker, M. (2004). Utjecaj leksičke granice na izgovor glasnika u artikulacijskom zglobu promatran elektropalatografski. Istraživanja govora. Peti znanstveni skup s međunarodnim sudjelovanjem "Istraživanja govora". Knjiga sažetaka. Vuletić, B., Horga, D., Mildner, V. (ur.). Zagreb: Hrvatsko filološko društvo, str. 37.

Horga, D., Mildner, V. (2004). The influence of temporal parameters on foreign accent. Teaching English for Life. Kučanda, D., Brdar, M., Berić, B. (ur.). Osijek: Filozofski fakultet, Sveučilište Josip Juraj Strossmayer, 41-50.

Horga, D., Požgaj Hadži, V. (2004). Govorna fluentnost u stranom jeziku: hrvatski i slovenski. Suvremena kretanja u nastavi stranih jezika. Stolac, D., Ivanetić, N., 
Pritchard, B., (ur.). Rijeka: Hrvatsko društvo za primijenjenu lingvistiku, 175185.

Ivičević-Desnica, J., Hunski, M., Horga, D. (2004). Odnos između govorne fluentnosti te izgovornog $\mathrm{i}$ ortodontskog statusa $\mathrm{u}$ predškolske djece. Peti znanstveni skup s međunarodnim sudjelovanjem "Istraživanja govora". Knjiga sažetaka. Vuletić, B., Horga, D., Mildner, V. (ur.). Zagreb: Hrvatsko filološko društvo, str. 45.

Štajner-Katušić, S., Horga, D., Vrban Zrinski, K. (2004). Postoperativni glas i govor nakon odstranjivanja polipa glasiljki. Peti znanstveni skup s međunarodnim sudjelovanjem "Istraživanja govora". Knjiga sažetaka. Vuletić, B., Horga, D., Mildner, V. (ur.). Zagreb: Hrvatsko filološko društvo, str. 102.

Vuletić, B., Horga, D., Mildner, V. (ur.) (2004). Istraživanja govora: peti znanstveni skup s međunarodnim sudjelovanjem: knjiga sažetaka. Zagreb: Hrvatsko filološko društvo.

Štajner-Katušić, S., Horga, D., Mušura, M., Globlek, D. (2004). Voice and Speech after Laryngectomy. 10th Meeting of the International clinical phonetics and linguistics association, Lafayette.

Globlek, D., Štajner-Katušić, S., Mušura, M., Horga, D., Liker, M. (2004). Comparison of alaryngeal voice and speech. Logopedics, phoniatrics, vocology, 29, 2; 87-91.

Globlek, D., Štajner-Katušić, S., Mušura, M., Horga, D., Liker, M. (2004). Akustička analiza alaringealnih glasova. Symposia otorhinolaryngologica, 34, 1 3; 13-17.

Runjić, N., Mildner, V., Horga, D., Šindija, B., Gregl, A. (2004). Hemisferalna dominantnost kod djece s umjetnom pužnicom. Peti znanstveni skup s međunarodnim sudjelovanjem "Istraživanja govora". Knjiga sažetaka. Vuletić, B., Horga, D., Mildner, V. (ur.). Zagreb: Hrvatsko filološko društvo, str. 94.

Štajner-Katušić, S., Horga, D., Mušura, M., Globlek, D., Liker, M. (2004). Voice and Speech after Laryngectomy. 2nd International Symposium "Tumors of the Head and Neck". Ivkić, M. (ur.). Zagreb: Dept. of ORL and Head and Neck Surg., Sestre milosrdnice, Univ. Hospital, 61-67.

Horga, D. (2005). Boundaries between linguistic units and articulatory joints. Iazyk, lichnost, tekst: sbornik statei k 70-letiiu T.M. Nikolaevoi, V.N. Toporov (ur.). Moskva: Jazyki slovjanskih kul'tur, 455-460.

Horga, D. (2005). Izgovorni zglobovi u spontanom govoru. Od fonetike do etike: zbornik o sedamdesetgodišnjici prof. dr. Josipa Silića. Pranjković, I. (ur.). Zagreb: Disput, 63-74. 
Horga, D. (2005). Obituary on Petar Guberina (1913 - 2005). The Phonetician, 1, 91; 19.

Horga, D. (2005). In Memoriam: Petar Guberina. Journal of the International Phonetic Association, 35, 2; 262.

Horga, D. (2005). Činitelj vremena u optimalnom slušanju. Dani Petra Guberine. Rehabilitacijske optimale. Zagreb: Poliklinika SUVAG, 12.

Horga, D. (2005). Utjecaj tempa na vremenske karakteristike govora. Pracouni vedecke setkani. Zdena Palkova (ur.). Prag: Univerzita Karlova v Praze, Filozoficka fakulta, 2.

Erdeljac, V., Horga, D. (2005). Govorne greške profesionalnih i neprofesionalnih govornika. 19. znanstveni skup s međunarodnim sudjelovanjem. Jezik $i$ mediji jedan jezik : više svjetova : zbornik. Granić J. (ur.). Split: Hrvatsko društvo za primijenjenu lingvistiku, 17, 65.

Horga, D., Požgaj Hadži, V. (2005). Slušateljeva redakcija govornika. Semantika prirodnog jezika i metajezik semantike. Granić, J. (ur.). Zagreb, Split: Hrvatsko društvo za primijenjenu lingvistiku, 301-310.

Horga, D., Požgaj Hadži, V. (2005). Između pitanja i odgovora. Jezik i mediji - jedan jezik : više svjetova : zbornik. 19. znanstveni skup s međunarodnim sudjelovanjem. Granić, J. (ur.). Split: Hrvatsko društvo za primijenjenu lingvistiku, 21, 65 .

Horga, D., Hunski, M., Ivičević-Desnica, J. (2005). Reorganizacija izgovora pod utjecajem umjetnog nepca. Revija za rehabilitacijska istraživanja, 40, 2; 201-209.

Horga, D., Ivičević-Desnica, J., Hunski, M. (2005). Interferencija manualnog zadatka i govora. Razvoj $i$ nove perspektive u jezičnoj $i$ govornoj terapiji $i$ dijagnostici. 3. kongres logopeda Hrvatske. Hercigonja Salamoni, D., Blaži, D. (ur.). Dubrovnik: Hrvatsko logopedsko društvo i Odsjek za logopediju ERF-a, 53-54.

Štajner-Katušić, S., Horga, D., Vrban Zrinski, K. (2005). Glas s polipom šest godina nakon fonokirurškog zahvata. Razvoj $i$ nove perspektive u jezičnoj $i$ govornoj terapiji $i$ dijagnostici. 3. kongres logopeda Hrvatske. Hercigonja Salamoni, D., Blaži, D. (ur.). Dubrovnik: Hrvatsko logopedsko društvo i Odsjek za logopediju ERF-a, str. 82.

Horga, D. (2006). Influence of Rate of Speech on Temporal Characteristics of Speech Segments. Kapitoly z fonetiky a fonologie slovanských jazyku. Palková, Z., Janoušková, J. (ur.). Prag: Univerzita Karlova v Praze, Filozofická fakulta, 155168. 
Erdeljac, V., Horga, D. (2006). Govorne greške profesionalnih i neprofesionalnih govornika. Jezik i mediji - jedan jezik : više svjetova : zbornik. Granić, J. (ur.). Zagreb-Split: Hrvatsko društvo za primijenjenu lingvistiku, 215-222.

Horga, D., Liker, M. (2006). Voice and pronunciation of cochlear implant speakers. Clinical Linguistics and Phonetics, 20, 2/3; 211-217.

Horga, D., Liker, M. (2006). Utjecaj leksičke granice na izgovor glasnika u artikulacijskom zglobu promatran elektropalatografski. Govor, 13, 2; 121-141.

Horga, D., Mildner, V. (ur.) (2006). ICPLA 2006: Book of Abstracts, Zagreb, Faculty of Humanities and Social Sciences, Department of Phonetics, Croatian Philological Association.

Horga, D., Požgaj Hadži, V. (2006). Između pitanja i odgovora. Jezik i mediji - jedan jezik: više svjetova : zbornik. Granić, J. (ur.). Zagreb-Split: Hrvatsko društvo za primijenjenu lingvistiku, 289-296.

Požgaj Hadži, V., Horga, D. (2006). Jezični identitet i spol. Jezik i identiteti. Granić, J. (ur.). Zagreb-Split: Hrvatsko društvo za primijenjenu lingvistiku, str. 35 i 76.

Horga, D., Požgaj Hadži, V., Liker, M. (2006). Časovne spremenljivke hrvaščine in slovenščine ter njun tujejezični jezikovni stik. SloFon1: 1. slovenska mednarodna fonetična konferenca (1st Slovene International Phonetic Conference). Jurgec, P. (ur.). Ljubljana: Inštitut za slovenski jezik Frana Ramovša ZRC SAZU, 31-32.

Štajner-Katušić, S., Horga, D., Vrban Zrinski, K. (2006). The Voice with the Polyp Six Years after Phonosurgery. ICPLA 2006: 11th Meeting of the International clinical phonetics and linguistic association. Horga, D., Mildner, V. (ur.). Zagreb: FF Press, str. 133.

Horga, D., Šikić, N., Akrap Kotevski, V., Ivičević-Desnica, J. (2006). Interrelation between voice, articulation and language in aphasia. ICPLA 2006: 11th Meeting of the International clinical phonetics and linguistics association. Horga, D., Mildner, V. (ur.). Zagreb: FF Press, str. 65.

Mušura, M., Štajner-Katušić, S., Globlek D., Horga, D. (2006). Voice and Speech after Laryngectomy. Zbornik sažetaka radova sa XVII. kongresa otorinolaringologa Srbije sa internacionalnim učš́cem i XLVI otorinolaringološke nedelje. Novi Sad, str. 28.

Štajner-Katušić, S., Horga, D., Mušura, M., Globlek, D. (2006). Voice and speech after laryngectomy. Clinical Linguistics and Phonetics, 20, 2/3; 195-203.

Horga, D. (2007). Phonetic research at the Department of Phonetics at the Faculty of Humanities and Social Sciencies at Zagreb University (Croatia). The Phonetician, 1, 95; 36-38. 
Horga, D. (2007). Prikaz knjige Gordane Kovačić: Akustička analiza glasa vokalnih profesionalaca. Revija za rehabilitacijska istraživanja, 43, 1; 117-118.

Horga, D. (2007). Retorika TV Dnevnika. Jezična politika i jezična stvarnost. Granić, J. (ur.). Zagreb, Split: Hrvatsko društvo za primijenjenu lingvistiku - HDPL, str. 24 i 70.

Škarić, I., Horga, D. (2007). Hrvatski jezik. Fonetika Fonologia: Komparacja wspolczesnych jezykow slowianskich 2, Sawicka, I. (ur.), Opole, Univerzitet Opolski, 531-555.

Horga, D., Ivičević-Desnica, J., Hunski, M. (2007). Vizualno zaznavanje artikulacijskega statusa govornikov. Zbornik povzetkov 2. kongresa logopedov Slovenije, Kvaliteta slovenske logopedije v europskem prostoru. Šavora, P.T., Zorko, N. (ur.). Maribor: MI BO d.o.o., 44-45.

Liker, M., Horga, D., Šafarić, I. (2007). Koartikulacijski pritisak i koartikulacijski otpor: ultrazvučno istraživanje. VI. znanstveni skup "Istraživanja govora". Knjiga sažetaka. Varošanec-Škarić i sur. (ur.). Zagreb: HFD, 76-77.

Požgaj Hadži, V., Horga, D., Bekavac, B. (2007). Jezični identiteti i spol. Jezik $i$ identiteti. Granić, J. (ur.). Zagreb, Split: Hrvatsko društvo za primijenjenu lingvistiku - HDPL, 447-486.

Liker, M., Gibbon, F. E., Wrench, A., Horga, D. (2007). Articulatory characteristics of the occlusion phase of $/ \mathrm{t} \mathrm{S} /$ compared to $/ \mathrm{t} / \mathrm{in}$ adult speech. Advances in Speech-Language Patholog, 9, 1; 101-108.

Mušura, M., Štajner-Katušić, S., Globlek, D., Horga, D. (2007). Komunikacija nakon laringektomije. 5. kongres Hrvatskog društva za otorinolaringologiju $i$ kirurgiju glave i vrata. Kalogjera, L., Ivkić, M., Vranješ, Ž. (ur.). Zagreb: Klinika za ORL, str. 165.

Šimunjak, B., Štajner-Katušić, S., Horga, D., Vrban Zrinski, K. (2007). Razabirljivost govora nakon parcijalnih zahvata na larinksu. Knjiga sažetaka, VI. znanstveni skup s međunarodnim sudjelovanjem "Istraživanja govora". Varošanec-Škarić, G., Horga, D. (ur.). Zagreb: FF press, str. 106.

Štajner-Katušić, S., Mušura, M., Horga, D., Globlek, D. (2007). Voice and Speech after Laryngectomy. European Archives of Otorhinolaryngology and Head and Neck Surgery. Olofson, J., Werner, J.A. (ur.). Berlin: Springer Verlag, str. 101.

Horga, D. (2008). Prekid izričaja i ponavljanje u govornoj proizvodnji. AUC Philologica, 11;31-42.

Horga, D. (2008). Repetitions in interrupted speech production. Beszedkutatas, 1; 157-171. 
Horga, D. (2008). Proizvodnja govora i izgovorne pogreške. Acta Universitatis Nicolai Copernici, 11; 43-54.

Akrap Kotevski, V., Ivičević-Desnica, J., Horga, D. (2008). Reaction time of word retrieval by aphasic subjects. Programme \& Book of Abstracts. Žemva, N., Papathanasiou, I. (ur.).Ljubljana: Institute for Rehabilitation Republic of Slovenia, str. 66.

Horga, D., Požgaj Hadži, V., Liker, M. (2008). Fonetski opis segmentalne razine hrvatskog jezika i sposobnost hrvatskih govornika u slušnom razlikovanju bošnjačkog, hrvatskog i srpskog govora. Slawische Sprachkorrelationen 1, Die Unterschiede zweschen dem Bosnischen/Bosniakischen, Kroatischen und Serbischen, Band 1. Tošović, B (ur.). Graz, Austrija: LIT, 187-199.

Horga D., Štajner-Katušić, S., Šafarić, I. (2008). Govorna komunikacija alaringealnih osoba. Lingvistika javne komunikacije. Brdar, M., Omazić, M. (ur.). Osijek: Hrvatsko društvo za primjenjenu lingvistiku, str. 29.

Liker, M., Horga, D., Šafarić, I. (2008). Koartikulacijski pritisak i koartikulacijski otpor: ultrazvučno istraživanje. Govor, 25, 2; 171-188.

Štajner-Katušić, S., Horga, D., Vrban Zrinski, K. (2008). A longitudinal study of voice before and after phonosurgery for removal of a polyp. Clinical linguistics $\mathcal{E}$ phonetics, 22, 10-11; 857-863.

Hunski, M., Carek, V., Badel, T., Horga, D., Ivičević-Desnica, J. (2008). Utjecaj totalne dentalne proteze na izgovor. Acta Stomatologica Croatica. Brkić, H. (ur.). Zagreb: Hrvatsko stomatološko društvo, 395-396.

Horga, D. (2009). U spomen, Ivo Škarić. Jezik, 41-80, 2; 41-49.

Horga, D., Požgaj Hadži, V. (2009). Retorika TV dnevnika. Med politiko in stvarnostjo; jezikovna situacija v novonastalih državah bivše Jugoslavije, Požgaj Hadži, V., Balažic Bulc, T., Gorjanc, V. (ur.). Ljubljana: Znanstvena založba Filozofske fakultete, 131-144.

Šafarić, I., Horga, D. (2009). Prostor u vremenskim prognozama. Prostor i vrijeme u jeziku: jezik u prostoru i vremenu. Brdar, M., Omazić, M., Pavičić Takač, V., Bagarić, V., Belaj, B., Kuna, B. (ur.). Zagreb-Osijek: Hrvatsko društvo za primijenjenu lingvistiku, 24-25.

Vidović, A., Horga, D. (2009). Vokalski prostor govornika kajkavskoga narječja Sisačke Gornje Posavine. Prostor i vrijeme u jeziku: jezik u prostoru i vremenu. Brdar, M., Omazić, M., Pavičić Takač, V., Bagarić, V., Belaj, B., Kuna, B. (ur.). Osijek: Hrvatsko društvo za primijenjenu lingvistiku, str. 60.

Horga, D., Požgaj Hadži, V., Šafarić, I. (2009). Fonetsko-fonološke razlike govora u beogradskom, sarajevskom i zagrebačkom televizijskom dnevniku. Slawische 
Sprachkorrelationen 2, Die Unterschiede zwischen dem Bosnischen/Bosniakischen, Kroatischen und Serbischen, Band 2. Tošović, B. (ur.). Graz, Austrija: LIT VERLAG. 379-392

Horga, D., Šafarić, I., Štajner-Katušić, S. (2009). Govorna komunikacija alaringealnih osoba. Lingvistika javne komunikacije: Sociokulturni, pragmalingvistički i stilistički aspekti. Brdar, M., Omazić, M., Belaj, B., Kuna, B. (ur.). Zagreb-Osijek: Hrvatsko društvo za primijenjenu lingvistiku, Filozofski fakultet Sveučilišta J.J. Strossmayera, 313-322.

Štajner-Katušić, S., Globlek, D., Mušura, M., Horga, D., Zrinski Vrban, K. (2009).Glas kod polipa na glasiljci i nakon fonokirurškog zahvata. Zbornik radova, Sažeci. Kalogjera, L., Ivkić, M., Živić, S. (ur.). Zagreb: Hrvatsko društvo za otorinolaringologiju i kirurgiju glave i vrata, str. 112.

Štajner-Katušić, S., Mateša, D., Horga, D., Šafarić, I., Katušić, D. (2009). Odnos vlastite procjene glasovnoga hendikepa i njegovih akustičkih parametara u laringektomiranih osoba, Zbornik radova, Sažeci. Kalogjera, L., Ivkić, M., Živić, S. (ur.). Zagreb: Hrvatsko društvo za otorinolaringologiju i kirurgiju glave i vrata, str. 111.

Horga, D., Požgaj Hadži, V., Liker, M. (2010). Fonetski opis segmentalne razine hrvatskog jezika i sposobnost hrvatskih govornika u slušnom razlikovanju bošnjačkog, hrvatskog i srpskog govora. Hrvatski pogledi na odnose između hrvatskoga, srpskoga $i$ bosanskogalbošnjačkoga jezika (Svezak 1), Tošović, B., Wonisch, A. (ur.). Graz, Zagreb: KFU, Izvori, 241-254.

Horga, D., Požgaj Hadži, V., Šafarić, I. (2010). Fonetsko-fonološke razlike govora u beogradskom, sarajevskom i zagrebačkom televizijskom dnevniku. Hrvatski pogledi na odnose između hrvatskoga, srpskoga i bosanskoga/bošnjačkoga jezika (Svezak 1), Tošović, B., Wonisch, A. (ur.). Graz, Zagreb: KFU, Izvori, 255-268. 